\title{
A 30-Year Scoping Review of the Physical Education Teacher Satisfaction Literature
}

By: K. Andrew R. Richards, Nicholas Washburn, Russell L. Carson \& Michael A. Hemphill

Richards, K. A. R., PhDWashburn, N., Carson, R. L. \& Hemphill, M. A. (2017). A 30-year scoping review of the physical education teacher satisfaction literature. Quest, 69(4), 494-514.

This is an Accepted Manuscript of an article published by Taylor \& Francis in Quest on March 29, 2017, available online:

http://www.tandfonline.com/10.1080/00336297.2017.1296365

\begin{abstract}
:
While stress has always been present in the teaching profession, recent trends such as standardized testing and school and teacher accountability may be making teachers' work more stressful. Teacher satisfaction research has emerged as a popular lens through which to understand how teachers experience their work. This scoping review sought to summarize the literature related to physical education teacher satisfaction published between 1987 and 2016. A total of 20 articles that reported research from 11 different countries were identified for inclusion. Thematic analysis of the study results led to the construction of four themes: (a) levels of physical education teacher satisfaction vary by level and context; (b) demographic variables do not reliably predict satisfaction; (c) intrinsic and psychosocial variables influence job satisfaction; and (d) the workplace and interpersonal relationships influence job satisfaction. Results are discussed and recommendations provided, particularly related to a theoretical basis for future research and methodological diversity.
\end{abstract}

Keywords: Affective events theory | teacher research | school context | physical education | scoping review

\section{Article:}

Teaching has long been considered a stressful occupation plagued with high rates of turnover (Ingersoll, 2003; Kyriacou \& Sutcliffe, 1978). Over 45 years ago, Ryan (1970) characterized the profession as the "ranks of the chalk-soiled, ink stained, over-challenged, under-supported, memo-ridden, privacy-riddled, patience-worn, school-fatigued, lovers of children and ideas" ( $p$. vi). More recently, issues stemming from standardized testing and school- and teacher-accountability (Valli, Croninger, \& Walters, 2007), the negative public perceptions of teachers (Koenig, 2014), and fluid and changing public policies surrounding education (McDonnell, 2012; Montgomery \& Rupp, 2005) have added to these challenges. The job experiences of physical education teachers (PETs) may lend themselves to different forms of 
stress resulting from issues such as marginalization (Kougioumtzis, Patriksson, \& Stråhlman, 2011), low perceived mattering (Richards, Gaudreault, \& Woods, 2016), isolation (Curtner-Smith, 2001), and in some countries such as the United States, conflict between the roles of PET and athletic coach (Richards \& Templin, 2012), which may not be common among classroom teachers.

At least in part due to these challenging work conditions and the stressors they produce, teacher turnover estimates hover near $16 \%$, and are considerably higher in high-poverty, urban schools (Goldring, Taie, \& Riddles, 2014). Further, using nationally representative and longitudinal data within the United States, Perda (2013) documented 41\% of neophyte teachers left the profession within their first 5 years. Teacher satisfaction is one area of research that has gained attention in relation to teacher retention (Kiliç \& Yazici, 2012; Lent et al., 2011; Skaalvik $\&$ Skaalvik, 2011). This work has its roots in the study of job and life satisfaction more generally (Hersey, 1932; Locke, 1969, 1976), which has largely operated under the generally-supported assumption that happy workers are more productive (see Judge, Thoresen, Bono, \& Patton, 2001). Job satisfaction is defined as an attitude based on the positive and negative evaluative judgments individuals hold toward their working roles (Weiss, 2002). A positive appraisal of one's job is often used to describe job satisfaction, while a negative appraisal is used to describe job dissatisfaction. Job satisfaction and dissatisfaction are not traditionally viewed as dichotomous, but rather at opposite ends on a continuum (Pinder, 1998). Further, the literature tends to recognize two different types of job satisfaction: global satisfaction and facet satisfaction (Judge et al., 2001; Skaalvik \& Skaalvik, 2011). Global satisfaction reflects general satisfaction with a job as a whole, while facet satisfaction refers to satisfaction in relation to specific elements of work (e.g., pay, supervision, collegiality, students).

While the literature related to teacher satisfaction is well established (Fairchild et al., 2012; Metzler, 2016; Platsidou \& Agaliotis, 2008), comparatively less is known about the PET satisfaction. The broader education literature offers some insight into workplace experiences that may facilitate or inhibit PET satisfaction, but the unique circumstances and experiences of PETs may lead to different levels of satisfaction, and that satisfaction may be derived from different sources (Carson, Richards, Hemphill, \& Templin, 2016). The current article reports the results of a scoping review (Anderson, Allen, Peckman, \& Goodwin, 2008) of the PET satisfaction literature. A brief overview of the general education teacher satisfaction literature is provided to ground the review and provide context for interpreting PETs' experiences.

\section{Overview of teacher satisfaction literature}

Traditionally, teachers reported relatively high levels of satisfaction. In previous decades, studies found that approximately $70 \%$ of surveyed teachers found teaching "very satisfying" to "fairly satisfying" (Borg, Riding, \& Falzon, 1991; Kyriacou \& Sutcliffe, 1978). Ellis and Bernhardt (1992) found that teachers, when compared to technical workers, service workers, and other persons with graduate degrees, were generally more motivated and satisfied. More 
recently, however, Markow and Pieters (2012) found that, between 2008 and 2012, the percentage of teachers indicating they were "very satisfied" with their jobs dropped from $62 \%$ to $39 \%$, which is the lowest value reported in 25 years. The percentage of teachers indicating that they felt very stressed several days per week increased from $36 \%$ to $51 \%$ during that same time - suggesting an inverse relationship between stress and teacher job satisfaction.

While documenting levels of teacher job satisfaction is important, identifying factors within the work environment that promote evaluative judgments of satisfaction and discourage those of dissatisfaction are, perhaps, of greater worth (Skaalvik \& Skaalvik, 2011). Most studies of teacher job satisfaction have been quantitative and used self-report survey instruments, such as the Minnesota Job Satisfaction Scale (Weiss, Dawis, England, \& Lofquist, 1967) and the Teacher Job Satisfaction Questionnaire (Lester, 1987). Generally, these studies examined demographic (e.g., gender, age, years of teaching experience, and teaching level), intrinsic (e.g., satisfaction derived from working with children), and work environment (e.g., pay, facilities) factors as predictors of satisfaction.

Demographic variables have not proven to be reliable determinants of teacher satisfaction. Female teachers have, by and large, reported more professional satisfaction than their male counterparts (Bogler, 2002; De Nobile \& McCormick, 2008; Ma \& MacMillan, 1999; Metzler, 2016); however, some studies indicated that males are more satisfied (Menon \& Athanasoula-Reppa, 2011), and others failed to find any significant gender effects (Crossman \& Harris, 2006; Klassen \& Anderson, 2009). Some studies concluded younger and less experienced teachers are more satisfied with their work (Perie \& Baker, 1997); however, other evidence indicates that older teachers (Griva \& Joekes, 2003) and those with more experience (Metzler, 2016) are more satisfied.

Stronger predictors of teacher satisfaction have been found when assessing various intrinsic and work environment variables. Workplace facets found to be satisfying to teachers include engaged and supportive administrators (e.g., upholds accountability practices, high expectations, encouraging, considerate), staff collegiality, and positive interactions with students (Ma \& MacMillan, 1999; Platsidou \& Agaliotis, 2008; Rhodes, Nevill, \& Allan, 2004). Additionally, variables such as positive affect (Duffy \& Lent, 2009), perceived teaching competence (Klassen \& Chiu, 2010; Perrachione, Petersen, \& Rosser, 2008), collegiality (Fairchild et al., 2012), and hospitable working conditions (Lent et al., 2011) have been predictive of satisfaction. In contrast, teachers identified being dissatisfied with a multitude of work facets such as low pay, large class size, limited resources, low parent interest, repressive administration, and excess bureaucracy. Additional work facets that have been linked with professional dissatisfaction include limited opportunities for decision making or having no sense of control at work, role conflict (i.e., difficulty reconciling inconsistency between varying expectations for job performance), role ambiguity (i.e., lack of information regarding expected performance of work duties), classroom misconduct, student violence, and student apathy (Dormann \& Kaiser, 2002; Klassen \& Anderson, 2009; Richardson \& Placier, 2001). 


\section{Purpose and research questions}

The broader literature related to teacher satisfaction offers some insight into workplace experiences that may facilitate or inhibit PET satisfaction, but it is also important to recognize disciplinary differences in teacher satisfaction levels. For example, differences in satisfaction between elementary and secondary teachers have been identified (Metzler, 2016; Perie \& Baker, 1997), and teachers of practical subjects (e.g., PE, woodwork, plastics) appear to be more satisfied with their jobs than those who teach theoretical subjects, such as mathematics, languages, or history (Van Maele \& Van Houtte, 2012).

In addition to differences in levels of satisfaction, PETs may derive satisfaction or dissatisfaction from different sources than classroom teachers (Carson et al., 2016). For these reasons, it has been recommended that subject affiliation be given consideration when designing studies related to teacher satisfaction (Badri, Mohaidat, Ferrandino, \& El Mourad, 2013). Given the need to recruit and retain effective teachers, and the association between teacher retention and job satisfaction (Kiliç \& Yazici, 2012; Lent et al., 2011; Skaalvik \& Skaalvik, 2011), it is imperative that researchers direct attention toward the study of PET job satisfaction. We acknowledge, however, Cochran-Smith and Zeichner's (2005) insistence that research questions and lines of inquiry be built upon previous work. The purpose of this manuscript was, therefore, to conduct a scoping review of the published research on PET satisfaction. Based on the results of this review, recommendations are provided for future research in this area.

\section{Literature review methodology}

Selecting an appropriate review procedure

In approaching the current review of PET satisfaction research, we were interested in examining the current body of literature and identifying gaps that could be filled through future studies. Influenced by the work of McEvoy, MacPhail, and Heikinaro-Johansson (2015), we viewed the literature similar to the ways in which "pieces of a jigsaw puzzle fit together. Each study represents a different piece, uniquely shaped and having its own place in the overall puzzle. With the addition of each piece the picture becomes clearer" (p. 163). This led us to select a scoping reviewing methodology rather than a systematic review. Whereas a systematic review seeks to evaluate the quality of the research that is surveyed, a scoping review is more concerned with providing a snapshot of the current body of literature in a particular area (Booth, Papaioannou, \& Sutton, 2012). Scoping reviews range in rigor from those that seek to provide a general account of the literature in an area to those that that fall just short of systematic reviews (Anderson et al., 2008). We locate the current review toward the more rigorous end of the spectrum as we sought to provide a comprehensive overview of the current literature related to PET satisfaction upon which to build recommendation for future scholarship. 
At the onset of the review process, we sought to develop boundaries based on our purpose for conducting the review (Anderson et al., 2008). In line with Arksey and O’Malley's (2005) criteria for conducting scoping reviews, our purposes were to summarize the existing literature and identify gaps that can be addressed through future inquiry. Given these criteria, the following research question was selected to guide the review: "What is the scope and content of peer-reviewed PET satisfaction research published between 1987 and 2016?" These boundaries were selected with the goal of identifying more recent trends in the literature over the past 30 years (Carson \& Raguse, 2014). We included studies published online in 2016, but were not yet officially in print. Articles in languages other than English were excluded due to limited access and complications associated with translation. Theoretical and conceptual articles related to PET satisfaction that did not include primary data were excluded from our review based on our stated research question. The review, therefore, was inclusive of all research related to PET satisfaction published in English between January 1, 1987 and December 31, 2016.

\section{Selection criteria}

One difference between a scoping review and a systematic review is that, in a systematic review, the criteria are developed at the onset of the study, whereas in a scoping review, they evolve throughout the screening process (McEvoy et al., 2015). The adaptation of criteria during the review process allows researchers to develop increased familiarity with the literature as they craft criteria for inclusion (Arksey \& O'Malley, 2005). In line with recommendations from the scoping review literature (Levac, Colquhoun, \& O'Brien, 2010), the first two authors met iteratively throughout the literature gathering process to discuss the inclusion criteria. The third author was consulted should there have been disagreement relative to the inclusion of specific articles. Studies were included in the review only if they: (a) were published in peer-reviewed journals, (b) focused specifically on the PET satisfaction in educational settings, (c) elaborated the methods used to collect and analyze data, and (d) provided conclusions that advanced the body of knowledge related to PET satisfaction.

Search strategies and sources

To make a contribution to the literature, a scoping review should be rigorous, transparent, and replicable (Arksey \& O’Malley, 2005). Our search strategies were influenced by the work of Carson and Raguse (2014) as well as McEvoy and colleagues (2015), and included three phases: (a) a search of electronic databases, (b) a manual search of key journals, and (c) a search of references in studies identified as meeting inclusion criteria. As articles were identified for inclusion, tables were created to document pertinent information (i.e., author[s], year, journal, 
country, purpose/aims, participants, data sources, data analysis procedures, and key findings). Article summaries were written to capture key findings from each study.

Electronic database search

The literature gathering process began with a search of the following four electronic databases: Academic Search Elite, ERIC, SportDiscus, and Web of Science. These databases were selected as they encompass the fields of education, sport, and health science. Google Scholar was also used as it is linked to our university's library system. The databases were searched for peer-reviewed publications from 1987 to 2016 that met the inclusion criteria. Specifically, we searched for articles that (a) were written in the English language, (b) contained the subject term "physical education teachers" and title term "job satisfaction" or "teacher satisfaction," (c) focused specifically on PET job satisfaction, and (d) were empirically-based. An initial review was conducted on all articles identified through the search. Articles that reported the results of empirical studies and appeared to focus on PET satisfaction $(n=151)$ were downloaded and the entire article was reviewed. Through this process, 125 articles did not meet the review criteria, and several other articles and book chapters $(\mathrm{n}=10)$ appeared to focus on PET satisfaction, but did not report primary results. They were, therefore, excluded from further processing. This resulted in the identification of 16 articles through the electronic database search.

Manual journal searches

Following the initial online search, and in concert with recommendations from the scoping review literature (Arksey \& O’Malley, 2005; McEvoy et al., 2015), a manual search was done of journals identified as likely to publish research related to PET satisfaction within the review window. Examples of journals surveyed include the Asia-Pacific Journal of Health, Sport and Physical Education; the European Physical Education Review; the Journal of Teaching in Physical Education; Physical Education and Sport Pedagogy; Research Quarterly for Exercise and Sport; and Sport, Education and Society. The titles and abstracts of all articles published between 1987 and 2016 were examined in reference to the inclusion criteria. Those that appeared to focus on PET satisfaction were downloaded and scanned for potential inclusion in the review. Three new articles were located in this search.

Reference list search

As a final step, we searched the reference list of all articles initially identified as potentially relevant $(n=151)$, as well as those found through the manual journal search $(n=3)$. The title of each referenced article was reviewed and those potentially relevant were accessed and reviewed in greater detail. This reference list search resulted in the inclusion of one new article not identified in previous steps of the literature gathering process.

\section{Overview of the current literature on PET satisfaction}


In total, 20 articles were located through the literature gathering process. These articles reported research conducted in 11 different countries: The United States $(n=4)$, Greece $(n=4)$, and India $(\mathrm{n}=3)$ were most common. Research methodologies were overwhelmingly quantitative ( $\mathrm{n}=19$; 95\%) - all of which used cross-sectional designs drawing upon self-report surveys. Table 1 overviews each of the individual studies included in the review, with reference to the countries in which the research was conducted, participants, data collection and analysis techniques, and major findings. The following sections of the review report a descriptive overview of the published articles, followed by a thematic review of study findings.

\begin{tabular}{|c|c|c|c|c|c|}
\hline No. & Authors & Participants and setting & Purpose & $\begin{array}{l}\text { Data } \\
\text { collection/analysis }\end{array}$ & Main results \\
\hline 1. & $\begin{array}{l}\text { Carson and } \\
\text { colleagues } \\
(2016)\end{array}$ & $\begin{array}{l}3 \text { PETs with } 25+\text { years } \\
\text { of experience in the } \\
\text { United States }\end{array}$ & $\begin{array}{l}\text { Understand the } \\
\text { TS of late career } \\
\text { PETs }\end{array}$ & $\begin{array}{l}\text { Satisfaction graphing } \\
\text { exercise and } \\
\text { interviews; inductive } \\
\text { analysis }\end{array}$ & $\begin{array}{l}\text { - Satisfaction } \\
\text { and } \\
\text { dissatisfaction } \\
\text { related to } \\
\text { working with } \\
\text { children, } \\
\text { administrators, } \\
\text { and } \\
\text { marginalization, } \\
\text { and relationships } \\
\text { with colleagues }\end{array}$ \\
\hline 2. & $\begin{array}{l}\text { Shivendra and } \\
\text { Kumar (2016) }\end{array}$ & $\begin{array}{l}75 \text { PETs across } \\
\text { government, } \\
\text { semi-government, and } \\
\text { private schools in India }\end{array}$ & $\begin{array}{l}\text { Examine the } \\
\text { relationship } \\
\text { among TS and } \\
\text { occupational } \\
\text { stress in } \\
\text { different types } \\
\text { of schools }\end{array}$ & $\begin{array}{l}\text { Job satisfaction scale } \\
\text { and occupational } \\
\text { stress index; one-way } \\
\text { ANOVA }\end{array}$ & $\begin{array}{l}\text { - Negative } \\
\text { relationship } \\
\text { observed between } \\
\text { satisfaction and } \\
\text { stress } \\
\text { - Stress highest } \\
\text { in private } \\
\text { schools; } \\
\text { satisfaction } \\
\text { highest in } \\
\text { government } \\
\text { schools }\end{array}$ \\
\hline 3. & $\begin{array}{l}\text { Mäkelä and } \\
\text { colleagues } \\
(2015)\end{array}$ & $\begin{array}{l}751 \text { ( } 342 \text { male, } 409 \\
\text { female) PETs in } \\
\text { Australia }\end{array}$ & $\begin{array}{l}\text { Determine the } \\
\text { aspects that keep } \\
\text { PETs happy and } \\
\text { in the profession }\end{array}$ & $\begin{array}{l}\text { Job satisfaction } \\
\text { questionnaire; } \\
\text { principal component } \\
\text { analysis, and logistic } \\
\text { regression }\end{array}$ & $\begin{array}{l}\text { - TS } \\
\text { significantly } \\
\text { related to teacher } \\
\text { retention } \\
\text { regardless of } \\
\text { experience } \\
\text { - Experienced } \\
\text { teachers more } \\
\text { impacted by } \\
\text { student } \\
\text { misconduct than } \\
\text { young teachers }\end{array}$ \\
\hline
\end{tabular}




\begin{tabular}{|c|c|c|c|c|c|}
\hline 4. & $\begin{array}{l}\text { Mäkelä and } \\
\text { Whipp (2015) }\end{array}$ & $\begin{array}{l}234 \text { PETs working in } \\
\text { Western Australia }\end{array}$ & $\begin{array}{l}234 \text { PETs } \\
\text { working in } \\
\text { Western } \\
\text { Australia }\end{array}$ & $\begin{array}{l}\text { PETs' career } \\
\text { intentions } \\
\text { questionnaire; t-tests, } \\
\text { and ANOVAs }\end{array}$ & $\begin{array}{l}\text { - } 39.8 \% \text { PETs } \\
\text { leaving } \\
\text { profession due to: } \\
\text { non-use of } \\
\text { expertise, } \\
\text { workload, } \\
\text { administration, } \\
\text { and lack of } \\
\text { professional } \\
\text { development }\end{array}$ \\
\hline 5. & $\begin{array}{l}\text { Pepe and } \\
\text { colleagues } \\
(2015)\end{array}$ & $\begin{array}{l}195 \text { randomly selected } \\
\text { PETs in Romania }\end{array}$ & $\begin{array}{l}\text { Determine } \\
\text { PETs' TS based } \\
\text { on gender, age, } \\
\text { status of } \\
\text { education, and } \\
\text { years teaching }\end{array}$ & $\begin{array}{l}\text { Teaching profession } \\
\text { attitude scale; t-tests, } \\
\text { and ANOVAs }\end{array}$ & $\begin{array}{l}\text { - Differences in } \\
\text { TS levels based } \\
\text { on age, gender, } \\
\text { and years of } \\
\text { service, but not } \\
\text { for education } \\
\text { - Generally, } \\
\text { attitude toward } \\
\text { teaching } \\
\text { decreases with } \\
\text { experience }\end{array}$ \\
\hline 6. & $\begin{array}{l}\text { Rutkowska } \\
\text { and Zalech } \\
(2015)\end{array}$ & $\begin{array}{l}\text { PETs }(\mathrm{n}=22) \text {, teachers } \\
\text { of other subjects }(\mathrm{n}= \\
\text { 22), and students }(\mathrm{n}= \\
\text { 22) in Poland }\end{array}$ & $\begin{array}{l}\text { Understand how } \\
\text { different } \\
\text { members of the } \\
\text { school perceive } \\
\text { the TS of PETs }\end{array}$ & $\begin{array}{l}\text { Satisfaction with life } \\
\text { scale (SWLS); group } \\
\text { differences assessed } \\
\text { using Mann-Whiteney } \\
\text { U test }\end{array}$ & $\begin{array}{l}\text { - PETs and } \\
\text { students } \\
\text { considered PETs' } \\
\text { TS to be low } \\
\text { - Teachers of } \\
\text { other subjects } \\
\text { considered PETs' } \\
\text { TS to be high }\end{array}$ \\
\hline 7. & Şentuna (2015 & $\begin{array}{l}213 \text { PETs ( } 137 \text { male, } \\
76 \text { female) in Turkey }\end{array}$ & $\begin{array}{l}\text { Study the } \\
\text { relationship } \\
\text { between TS, } \\
\text { commitment, } \\
\text { and self-esteem } \\
\text { levels in male } \\
\text { and female } \\
\text { PETs }\end{array}$ & $\begin{array}{l}\text { Rosenberg self-esteem } \\
\text { scale, job satisfaction } \\
\text { scale, and } \\
\text { organizational } \\
\text { commitment scale; } \\
\text { t-tests }\end{array}$ & $\begin{array}{l}\text { - Male PETs } \\
\text { reported higher } \\
\text { TS, } \\
\text { organizational } \\
\text { commitment, and } \\
\text { self-esteem than } \\
\text { female PETs }\end{array}$ \\
\hline 8. & $\begin{array}{l}\text { Yildirim } \\
(2015)\end{array}$ & 306 PETs in Turkey & $\begin{array}{l}\text { Examine the } \\
\text { correlation } \\
\text { between } \\
\text { self-efficacy and } \\
\text { TS }\end{array}$ & $\begin{array}{l}\text { Self-efficacy scale and } \\
\text { Minnesota job } \\
\text { satisfaction } \\
\text { questionnaire short } \\
\text { form; structural } \\
\text { equation modeling }\end{array}$ & $\begin{array}{l}\text { - Self-efficacy } \\
\text { and TS of the } \\
\text { PETs were high. } \\
\text { There was a } \\
\text { significant, } \\
\text { positive } \\
\text { correlation } \\
\text { between } \\
\text { self-efficacy and } \\
\text { TS }(r=0.30, t= \\
4.02)\end{array}$ \\
\hline 9. & $\begin{array}{l}\text { Ješinová and } \\
\text { colleagues }\end{array}$ & $\begin{array}{l}113 \text { adapted PETs in } \\
\text { the United States }\end{array}$ & $\begin{array}{l}\text { Identify factors } \\
\text { causing job }\end{array}$ & $\begin{array}{l}\text { Job satisfaction } \\
\text { questionnaire; }\end{array}$ & $\begin{array}{l}\text { - Job } \\
\text { dissatisfaction }\end{array}$ \\
\hline
\end{tabular}




\begin{tabular}{|c|c|c|c|c|c|}
\hline & (2014) & & $\begin{array}{l}\text { dissatisfaction } \\
\text { among adapted } \\
\text { PETs }\end{array}$ & percentage rankings & $\begin{array}{l}\text { factors included: } \\
\text { working } \\
\text { conditions ( } 71 \%) \text {; } \\
\text { policies and } \\
\text { administration } \\
(68 \%) ; \\
\text { relationship with } \\
\text { supervisors } \\
(61 \%) \text {, } \\
\text { subordinates } \\
(45 \%) \text {, and peers } \\
(32 \%) ; \\
\text { supervision } \\
(54 \%) \text {; salary } \\
(45 \%) ; \text { benefits } \\
\text { on job (33\%); } \\
\text { and job security } \\
(27 \%)\end{array}$ \\
\hline 10. & $\begin{array}{l}\text { Morolia and } \\
\text { Tiwari (2012) }\end{array}$ & 500 PETs in India & $\begin{array}{l}\text { Identify TS level } \\
\text { of PETs based on } \\
\text { their level of job } \\
\text { stress }\end{array}$ & $\begin{array}{l}\text { Job stress and job } \\
\text { satisfaction scales; } \\
\text { multiple regression }\end{array}$ & $\begin{array}{l}\text { - A significant } \\
\text { negative } \\
\text { relationship } \\
\text { between job } \\
\text { stress and TS }\end{array}$ \\
\hline 11. & $\begin{array}{l}\text { Mousavi and } \\
\text { colleagues } \\
(2012)\end{array}$ & 215 PETs in Iran & $\begin{array}{l}\text { Study the } \\
\text { relationship } \\
\text { between } \\
\text { emotional } \\
\text { intelligence and } \\
\text { TS }\end{array}$ & $\begin{array}{l}\text { Emotional intelligence } \\
\text { scale and job feeling } \\
\text { scale; stepwise } \\
\text { regression }\end{array}$ & $\begin{array}{l}\text { - There is a } \\
\text { significant } \\
\text { positive } \\
\text { relationship } \\
\text { between PETs' } \\
\text { emotional } \\
\text { intelligence } \\
\text { (empathy, } \\
\text { motivation, social } \\
\text { skills factors) and } \\
\text { their TS }\end{array}$ \\
\hline 12. & $\begin{array}{l}\text { Topič and } \\
\text { Mujanović } \\
\text { (2012) }\end{array}$ & 334 PETs in Slovenia & $\begin{array}{l}\text { Determine the } \\
\text { TS of PETs in } \\
\text { Slovenian } \\
\text { schools }\end{array}$ & $\begin{array}{l}\text { Survey of satisfaction } \\
\text { with working } \\
\text { conditions and } \\
\text { relationships; t-tests, } \\
\text { and ANOVAs }\end{array}$ & $\begin{array}{l}\text { - TS of PETs in } \\
\text { Slovenia in } \\
\text { general is very } \\
\text { high. } \\
\text { - PETs more } \\
\text { satisfied with } \\
\text { their work were: } \\
\text { working in } \\
\text { smaller schools, } \\
\text { at the primary } \\
\text { level, male, and } \\
\text { working under a } \\
\text { principal who } \\
\text { was also a PET. }\end{array}$ \\
\hline 13. & $\begin{array}{l}\text { Dhurup and } \\
\text { Mahomed } \\
\text { (2011) }\end{array}$ & $\begin{array}{l}128 \text { PETs in South } \\
\text { Africa }\end{array}$ & $\begin{array}{l}\text { Examine the } \\
\text { relationship } \\
\text { between role }\end{array}$ & $\begin{array}{l}\text { Role stress survey and } \\
\text { job description index; } \\
\text { multiple regression }\end{array}$ & $\begin{array}{l}\text { - Significant } \\
\text { negative } \\
\text { relationships }\end{array}$ \\
\hline
\end{tabular}




\begin{tabular}{|c|c|c|c|c|c|}
\hline & & & stressors and TS & & $\begin{array}{l}\text { were found } \\
\text { between the role } \\
\text { stressors and TS. } \\
\text { High levels of } \\
\text { role stress } \\
\text { predicted low TS. }\end{array}$ \\
\hline 14. & $\begin{array}{l}\text { Amarantidou } \\
\text { and colleagues } \\
(2009)\end{array}$ & 117 PETs in Greece & $\begin{array}{l}\text { Investigate the } \\
\text { relationship } \\
\text { between job } \\
\text { security and TS }\end{array}$ & $\begin{array}{l}\text { Employee satisfaction } \\
\text { inventory and } \\
\text { Minnesota satisfaction } \\
\text { questionnaire; } \\
\text { descriptive statistics } \\
\text { and correlations }\end{array}$ & $\begin{array}{l}\text { - Job security } \\
\text { improved PETs' } \\
\text { facet (specific) } \\
\text { satisfaction of job } \\
\text { supervision, } \\
\text { which directly } \\
\text { effects global } \\
\text { (overall) } \\
\text { satisfaction. }\end{array}$ \\
\hline 15. & $\begin{array}{l}\text { Kumar and } \\
\text { Bhatia (2009) }\end{array}$ & $\begin{array}{l}65 \text { secondary PETs in } \\
\text { India }\end{array}$ & $\begin{array}{l}\text { Compare PETs' } \\
\text { TS and their } \\
\text { attitude toward } \\
\text { teaching }\end{array}$ & $\begin{array}{l}\text { Job satisfaction and } \\
\text { work attitude } \\
\text { questionnaires; t-tests }\end{array}$ & $\begin{array}{l}\text { - TS and attitude } \\
\text { toward teaching } \\
\text { not significantly } \\
\text { correlated nor } \\
\text { affected by the } \\
\text { gender, marital } \\
\text { status, and } \\
\text { income. }\end{array}$ \\
\hline 16. & $\begin{array}{l}\text { Koustelios } \\
(2005)\end{array}$ & 115 PETs in Greece & $\begin{array}{l}\text { Examine the } \\
\text { relationship } \\
\text { between TS and } \\
\text { personal } \\
\text { characteristics }\end{array}$ & $\begin{array}{l}\text { Employee satisfaction } \\
\text { inventory; t-tests and } \\
\text { ANOVAs }\end{array}$ & $\begin{array}{l}\text { - PETs were } \\
\text { globally (overall) } \\
\text { satisfied with } \\
\text { their jobs, but not } \\
\text { with facets } \\
\text { (specifics) of } \\
\text { promotions, pay, } \\
\text { and working } \\
\text { conditions. } \\
\text { - Differences in } \\
\text { gender, age, and } \\
\text { experience. }\end{array}$ \\
\hline 17. & $\begin{array}{l}\text { Koustelios and } \\
\text { Tsigils (2005) }\end{array}$ & 175 PETs in Greece & $\begin{array}{l}\text { Examine the } \\
\text { multivariate } \\
\text { relationship } \\
\text { between TS and } \\
\text { burnout }\end{array}$ & $\begin{array}{l}\text { Maslach burnout } \\
\text { inventory and } \\
\text { employee satisfaction } \\
\text { inventory; t-tests }\end{array}$ & $\begin{array}{l}\text { - Greek PETs } \\
\text { generally } \\
\text { experience high } \\
\text { satisfaction and } \\
\text { low burnout. } \\
\text { - Intrinsic factors } \\
\text { correlate strongly } \\
\text { with TS; extrinsic } \\
\text { factors correlated } \\
\text { stronger with } \\
\text { burnout. }\end{array}$ \\
\hline 18. & $\begin{array}{l}\text { Koustelios and } \\
\text { colleagues } \\
\text { (2004) }\end{array}$ & 61 PETs in Greece & $\begin{array}{l}\text { Examine role } \\
\text { the relationship } \\
\text { among role } \\
\text { stressors and TS }\end{array}$ & $\begin{array}{l}\text { Employee satisfaction } \\
\text { inventory and a role } \\
\text { stressor questionnaire; } \\
\text { multiple regression }\end{array}$ & $\begin{array}{l}\text { - PETs satisfied } \\
\text { with the job } \\
\text { itself, } \\
\text { supervision, and }\end{array}$ \\
\hline
\end{tabular}




\begin{tabular}{|l|l|l|l|l|l|}
\hline & & & & & $\begin{array}{l}\text { working } \\
\text { conditions; } \\
\text { dissatisfied with } \\
\text { salary and } \\
\text { promotional } \\
\text { opportunities } \\
\text { Increased role } \\
\text { conflict and role } \\
\text { ambiguity } \\
\text { lowered TS }\end{array}$ \\
\hline 19. & $\begin{array}{l}\text { Green-Resse } \\
\text { and colleagues } \\
\text { (1991) }\end{array}$ & $\begin{array}{l}229 \text { secondary teachers } \\
\text { in urban school in the } \\
\text { United States }\end{array}$ & $\begin{array}{l}\text { Determine } \\
\text { differences in } \\
\text { TS and stress } \\
\text { according to } \\
\text { age, teaching } \\
\text { experience, and } \\
\text { school size }\end{array}$ & $\begin{array}{l}\text { Job satisfaction scale; } \\
\text { job stress scale; } \\
\text { one-way ANOVAs }\end{array}$ & $\begin{array}{l}\text { - School size } \\
>1,500 \text { students } \\
\text { adversely affects } \\
\text { teachers' TS. } \\
\bullet \text { Neither age nor } \\
\text { experience } \\
\text { predicted TS or } \\
\text { stress. }\end{array}$ \\
\hline 20. & $\begin{array}{l}\text { Reese and } \\
\text { Johnson } \\
(1988)\end{array}$ & $\begin{array}{l}229 \text { secondary teachers } \\
\text { in urban school in the } \\
\text { United States }\end{array}$ & $\begin{array}{l}\text { Investigate the } \\
\text { relationship } \\
\text { between school } \\
\text { size, gender, } \\
\text { experience, and } \\
\text { TS }\end{array}$ & $\begin{array}{l}\text { Job satisfaction scale; } \\
\text { one-way ANOVAs }\end{array}$ & $\begin{array}{l}\text { Regardless of } \\
\text { gender and } \\
\text { teaching } \\
\text { experience, } \\
\text { teachers in } \\
\text { schools serving } \\
>1,500 \text { students } \\
\text { reported lower } \\
\text { TS. }\end{array}$ \\
\hline
\end{tabular}

Descriptive overview of the published studies

Temporally, the studies were categorized as being published within one of three 10-year periods: 1987-1996, 1997-2006, and 2007-2016. Examination of the studies published across these time periods indicates that inquiry into PETs' job satisfaction, though still nominal, has gained attention over the past 30 years. Only $10 \%$ of the papers $(n=2)$ were published between 1987 and 1996, 20\% $(\mathrm{n}=4)$ were published from 1997 through 2006 , and the remaining $70 \%(\mathrm{n}=14)$ had publication dates between 2007 and 2016. This indicates that, while relatively few studies on PET satisfaction were published in the 30-year review window, attention has markedly increased over time. Publication outlets, theoretical frameworks, study purposes, authorship, participants, and methods for all articles are examined in the following sections.

\section{Publication outlets}

Outlets that have published PET satisfaction research in the review window were examined. In total, the 20 different studies were published across 14 journals. Four (28.6\%) of these journals published disciplinary research specific to PE, while 10 (71.4\%) have a broader scope (e.g., general education). The four PE disciplinary journals accounted for seven (35\%) of the 20 
articles. These included the African Journal for Physical, Health Education, Recreation and Dance $(n=1)$, the European Physical Education Review $(n=2)$, the International Journal of Physical Education $(n=2)$, and the Journal of Teaching in Physical Education $(n=2)$. The remaining 10 non-PE journals each published either one or two articles. Considering the limited number of publications, the diversity in outlets may make it difficult for researchers to access what work is available, particularly those who rely primarily on PE disciplinary journals.

Theoretical frameworks

Each article was read specifically for the mention of a guiding theoretical framework. Only one study (Ješinová, Spurná, Kudláček, \& Sklenaříková, 2014) referenced a specific theoretical framework. This study used Herzberg, Mausner, and Snyderman's (1957) two-factor theory of job satisfaction, which delineates between job satisfaction and dissatisfaction. None of the other studies in the review included reference to theoretical frameworks, and instead were grounded solely in the teacher satisfaction literature.

\section{Authorship}

In order to understand the breadth of authorship and the contributions made by individual authors to the PET satisfaction literature, a series of descriptive analyses were undertaken. A total of 41 different authors contributed to the 20 articles. These authors were affiliated with universities in 11 different countries, including the United States $(n=7 ; 17.07 \%)$, Greece $(n=6 ; 14.63 \%)$, India $(n=6 ; 14.63 \%)$, the Czech Republic $(n=4 ; 9.75 \%)$, Iran $(n=4 ; 9.75 \%)$, Finland $(n=3$; $7.31 \%)$, Romania $(n=3 ; 7.31 \%)$, Poland $(n=2 ; 4.87 \%)$, Slovenia $(n=2 ; 4.87 \%)$, South Africa $(\mathrm{n}=2 ; 4.87 \%)$, and Turkey $(\mathrm{n}=2 ; 4.87 \%)$. To better understand the contributions made by individual authors, the number of authors per study was examined. There were between one and six authors per manuscript, with an average of 2.4 per study. Most of the studies included multiple authors $(n=17 ; 85 \%)$, with two authors being most common $(n=9 ; 45 \%)$. Each author appeared on an average of 2.05 studies, but only five appeared on more than one publication. The most active author contributed to four $(20 \%)$ of the publications. Together, these five authors accounted for more than half $(\mathrm{n}=12 ; 60 \%)$ of the published studies.

\section{Participants}

The section reporting information on participants was reviewed in each article to understand who the participants were and how many were included. It became clear that information related to participants was not reported consistently across the studies. As a result, the analysis was limited to the number, gender, and role of participants. The 19 quantitative studies included in this review involved a total of 4,121 participants. Participants in the studies ranged from a high of 751 (Mäkelä, Hirvensalo, \& Whipp, 2015) to a low of 61 (Koustelios, Theodorakis, \& Goulimaris, 2004), and the average paper included $216.89(\mathrm{SD}=169.84)$ participants. The majority $(n=4,077 ; 98.93 \%)$ of participants were PETs, but there was a smaller group of students $(n=22 ; 0.53 \%)$ and non-PETs $(n=22 ; 0.53 \%)$. Gender information was only reported 
in 12 of the studies (63.16\%). Among those reporting, there were 1,343 males $(51.77 \%)$ and 1,251 females $(48.23 \%)$. The only available qualitative study (Carson et al., 2016) included three middle school PETs ( 2 female, 1 male) who had been teaching between 17 and 28 years. One of the teachers had a bachelor's degree, and the other two had earned master's degrees.

\section{Methods}

In order to more fully understand the type of PET satisfaction research that has been conducted, analyses were performed to examine study methods relative to research design and data collection and analysis procedures. Most of the studies $(n=19 ; 95 \%)$ used quantitative methods. All of these investigations were cross-sectional and relied on self-report surveys. Based on McBride's (2013) classification system, most studies were predictive $(n=15 ; 78.95 \%)$ with fewer adopting descriptive $(n=4 ; 21.05 \%)$ designs. None of the studies were classified as causal. The most common analytic approaches included analyses of variance (ANOVAs) $(n=6)$, correlations $(n=4)$, and regression $(n=4)$. Examples of less common techniques include structural equation modeling, multivariate analysis of variance (MANOVA), and the Mann-Whitney U-test. Internal consistency reliability of the measures was provided in 10 of the 19 quantitative studies (52.63\%). The lone qualitative study (Carson et al., 2016) used a phenomenological approach by relying on interviews and a job satisfaction graphing technique. Data were analyzed via inductive analysis and constant comparison. Efforts to enhance trustworthiness included member checks, researcher triangulation, and peer debriefing.

\section{Thematic results of the review}

The individual article summaries created during the article review phase were used to determine what themes were addressed in each article. These summaries were content analyzed into emergent categories by the second author (Patton, 2015). The first and second authors then worked collectively to refine the themes until consensus was reached. Final themes included: (a) levels of PET satisfaction vary by level and context, (b) demographic variables do not reliably predict satisfaction, (c) intrinsic and psychosocial variables influence job satisfaction, and (d) the workplace and interpersonal relationships influence job satisfaction.

Levels of PET satisfaction vary by country and context

Given that the studies included in the review reflect 11 different countries, an analysis was undertaken to understand how PET satisfaction levels vary across nationalities. This analysis indicated that teachers across geographical boundaries experience differing levels of satisfaction. Teachers in the United States contend with relatively negative public perceptions of their profession (Koenig, 2014), whereas teachers are afforded significantly more respect in countries such as Finland (Mäkelä, Hirvensalo, Laakso, \& Whipp, 2014). These contexts may lead to different experiences for PETs. Results of the review generally support this hypothesis. Studies conducted in Slovenia (Topič \& Mujanović, 2012), Turkey (Yildirim, 2015), and Greece 
(Koustelios \& Tsigilis, 2005) reported PETs as being quite satisfied with their work. For example, on a 5-point scale, Topič and Mujanović (2012) discovered that a sample of Slovenian PETs $(n=334)$ expressed satisfaction (i.e., $\geq 3.3$ on a 5-point, Likert-type scale) with 17 of the 18 items related to working conditions and relationships. The only aspect of their jobs with which the Slovenian PETs expressed relative dissatisfaction was class sizes $(M=2.96)$.

In contrast, PETs working in Australia have reportedly been less satisfied with their work. In a sample of 234 Australian PETs, almost 40\% indicated their intention to leave PE teaching because they were dissatisfied (Mäkelä \& Whipp, 2015). Moreover, a sample of 751 Australian PETs in Mäkelä and colleagues' (2015) study were classified as being either lifers (i.e., satisfied and enthusiastic) or troupers (i.e., dissatisfied and unenthusiastic). Results indicated that nearly half $(\mathrm{n}=311 ; 41 \%)$ were troupers. In a similar vein, $39.8 \%$ of the 113 U.S.-adapted PETs surveyed by Ješinová and colleagues (2014) specified they were seriously considering a career change due to dissatisfaction. Some evidence suggests that students and colleagues have different evaluations of PETs' satisfaction than the teachers themselves. In Poland, Rutkowska and Zalech (2015) found that, while teachers of other subjects perceived PETs as being satisfied, students and PETs themselves tend to report lower satisfaction levels. Finally, in a study of Australian PETs, job satisfaction has been found to predict intention to remain in the teaching profession (Mäkelä et al., 2015).

Demographic variables do not reliably predict satisfaction

As with the general education teacher satisfaction literature (e.g., Ma \& MacMillan, 1999; Menon \& Athanasoula-Reppa, 2011), results from studies examining the influence of demographic variables are mixed. Some evidence indicates that female PETs are more satisfied than males (Koustelios, 2005; Pepe, Turan, \& Bahadir, 2015), while others found that males are more satisfied than females (Şentuna, 2015; Topič \& Mujanović, 2012), and that the effect of gender is marginal (Kumar \& Bhatia, 2009). Pepe and colleagues (2015) discovered higher satisfaction levels among younger (25-30 years of age) and less-experienced (1-5 years of experience) PETs relative to those who were older (31-45 years of age) and had been teaching longer (16-20 years of experience). The authors attributed this difference to younger teachers' desire to prove themselves and improve their performance. Green-Reese, Johnson, and Campbell (1991), however, reported no differences with regard to age and experience. Additional variables, including marital status, education, school level, and income have been shown to have little impact on PET satisfaction (Kumar \& Bhatia, 2009; Pepe et al., 2015; Topič \& Mujanović, 2012).

Intrinsic and psychosocial variables influence job satisfaction Research focused on the influential role played by intrinsic, perceptually-based factors appears to yield more reliable results than examining demographic variables. Self-efficacy has been shown to correlate positively with teacher satisfaction across multiple studies (Mäkelä et al., 2015; Yildirim, 2015). Emotional intelligence, which is the capacity of humans to recognize their 
emotions and those of others (Goleman, 1988), has been found to relate positively to PET satisfaction (Mousavi, Yarmohammadi, Nosrat, \& Tarasi, 2012). More specifically, among the five components of emotional intelligence, social skills, empathy, and motivation were predictive of job satisfaction. Inversely, role stress in the form of role ambiguity (i.e., expectations for satisfactory performance are unclear), conflict (i.e., competing sets of expectations), and overload (i.e., excessive expectations) have all been documented as relating negatively with PETs' job satisfaction levels (Dhurup \& Mahomed, 2011; Koustelios et al., 2004).

The workplace and interpersonal relationships influence job satisfaction In addition to intrinsic and psychosocial experiences, structural elements of the workplace and relationships with others have been found to influence PET job satisfaction. School size appears to affect teacher satisfaction, with research indicating that PETs are more satisfied working in smaller schools (Topič \& Mujanović, 2012). At the secondary level, PETs working in schools serving less than 1,500 students were significantly more satisfied with their work than PETs working in larger schools (Green-Reese, Johnson, \& Campbell, 1991; Reese \& Johnson, 1988). Additional work environment factors that appear to positively relate to PET satisfaction include having a principal with PE teaching experience, having access to adequate and quality resources, receiving recognition of quality teaching performance, teaching a manageable schedule, and working with cooperative students (Mäkelä et al., 2015; Topič \& Mujanović, 2012). In a survey of 175 Greek PETs, Koustelios and colleagues (2004) found that supportive leadership and positive working conditions positively predicted job satisfaction. In the only qualitative study published to date, Carson and colleagues (2016) identified autonomy from administrator oversight, a sense of control over their classes, and close collegial relationships as sources of facet satisfaction. Inversely, low salary, lack of professional prestige, and limited opportunities for advancement have been shown to predict dissatisfaction (Koustelios et al., 2004).

\section{Advancing the study of teacher satisfaction in PE}

The purpose of this scoping review of literature was to examine the current state of the literature and make recommendations for future scholarship. Descriptive results of the review suggest that, while PET satisfaction research has been conducted in 11 different countries, it has not been studied more than four times in any one country. Thus, additional attention is needed to understand PET satisfaction on a global level. Results also indicate that PET satisfaction research is void of theory, and that a small number of researchers $(n=5)$ contributed to over half $(60 \%)$ of the published research. Thematic results indicate that PET satisfaction seems to vary based on cultural context, and that demographic variables have not been consistent predictors of PET satisfaction. Intrinsic variables, such as intellectual stimulation and role stress, and contextual factors, such as resources and relationships with others, have been more consistent predictors.

This scoping review has indicated that the PET satisfaction literature is rather under-developed, and that additional research is warranted. The expansion of this line of inquiry 
is particularly important given that PETs may experience the school day differently than general education teachers (Carson et al., 2016), and many cope with the challenges of marginalization (Lux \& McCullick, 2011), isolation (Curtner-Smith, 2001), and teacher/coach role stress (Richards \& Templin, 2012). For example, research in general education has indicated that administrative support is a predictor of teacher satisfaction (Bogler, 2002; Buyukgoze-Kavas, Duffy, Güneri, \& Autin, 2014), while some evidence indicates that PETs prefer autonomy from administrator oversight (Carson et al., 2016). In the following sections, we consider future directions related to PET satisfaction research based on the current state of the literature. We specifically focus on developments possible through affective events theory (AET; Weiss \& Cropanzano, 1996), discuss the importance of methodological diversity, and outline implications for practice based on existing and future research.

Developing and theoretical basis for research: AET

As the literature related to PET satisfaction continues to develop, it is important for this work to adopt a theoretical foundation, especially given that all of the existing literature was essentially atheoretical. While multiple theoretical frameworks are potentially appropriate for the study of PET satisfaction, one which offers particular relevance is AET (Weiss \& Cropanzano, 1996). Beginning in the later part of the 20th century, researchers began asking more in-depth questions about the causes and consequences of specific emotions in the workplace (Brief \& Weiss, 2002; Briner, 1999; Payne \& Cooper, 2001). Along these lines, Weiss and Cropanzano (1996) presented AET as a way to distinguish and study emotions, mood, and satisfaction at work. The most basic assumption of AET - job satisfaction is an evaluative judgment of one's job - is in line with most other theories of job satisfaction (e.g., Herzberg et al., 1957; Wegge, van Dick, Fisher, West, \& Dawson, 2006). However, AET offers the additional advantage of distinguishing between the job in general (i.e., global satisfaction), specific features of the job (i.e., facet satisfaction), and emotional states. These emotional states are recognized to have consequences distinguishable from the causes of the evaluative judgments related to satisfaction and dissatisfaction (Carlson, Kacmar, Zivnuska, \& Ferguson, 2011).

Through AET, job-related attitudes (i.e., global satisfaction) and affect are distinguished by both (a) the causal role of work environment facets (e.g., administrators, co-workers, student behavior) and (b) behavioral consequences (e.g., being particularly enthusiastic or curt during a class; Weiss \& Cropanzano, 1996). In other words, AET proposes that work facets influence employees' global satisfaction directly and indirectly through the recollection of affective responses (e.g., happy, sad, agitated, content) to work facets over time. Teachers' global satisfaction can be directly derived from their appraisals of their work facets (e.g., "I do not have many problems with students at this school") and indirectly from the summation of times they feel good or bad about work facets (e.g., "effort students displayed in my second period class made my day"). Negative events in the workplace are believed to trigger negative emotional reactions, and positive events trigger positive reactions (Zhao, Wayne, Glibkowski, \& Bravo, 
2007). Evidence, however, indicates that individuals interpret work events differently, thus allowing one person to experience a positive reaction to an event, while another experiences a negative reaction to the same event (Avery, Wernsing, \& Luthans, 2008).

Another benefit of adopting AET to studying teacher satisfaction is that it forges a connection between teachers' emotional state, satisfaction, and resulting behaviors. Researchers using AET postulate that the overall attitude individuals hold about their job transpires into different forms of behavior than that driven by the immediate nature of an affective experience (Weiss \& Cropanzano, 1996). Judgment-driven behaviors are intentional, calculated responses that are the result of the attitudes that one holds toward the work environment. These behaviors are impacted directly by workplace facets and the affective responses that one has in relation to these facets over time (Wegge et al., 2006). For instance, teachers may retire earlier than expected because they are dissatisfied with student behavior and have had difficult classes across multiple years. This behavior is different than the affect-driven behaviors possibly displayed when teachers are in a bad mood because of having to handle challenging students in particular classes. In these situations, the teacher's affective responses to the work facets are driving more spontaneous behaviors (Rupp \& Spencer, 2006). In essence, being satisfied or dissatisfied with one's job overall drives different behaviors than those emanating from affective reactions to specific work facets at a particular point in time.

To illustrate the relationships forwarded by AET, we trace the experiences of Sandy, a teacher in Carson and colleagues' (2016) qualitative study of PET satisfaction, through Figure 1, letters a through h. Pathways in the figured are marked with letters a through g. Sandy worked in an environment where she believed that class sizes were too large, which directly influenced work attitudes (a). She was then informed that she would be having larger classes next year (b), which led to work frustration and a negative affective reaction (c). She had a disposition that emphasized autonomy over her teaching space, which moderates the relationship between the work event (i.e., being informed that class sizes would be increasing) and her negative affective reaction (e), and influenced the reaction itself (d). Sandy's negative affective reaction to the increase in class sizes led to increased job dissatisfaction (f), as well as a negative, affect-driven behavioral response, which manifested through more callous interactions with students in classes immediately following the news (h). Her increased job dissatisfaction, influenced by the workplace facet of having larger class sizes and her affective reaction to that change, could result in a negative judgment-driven behavior (g), such as deciding to leave the teaching profession early. 


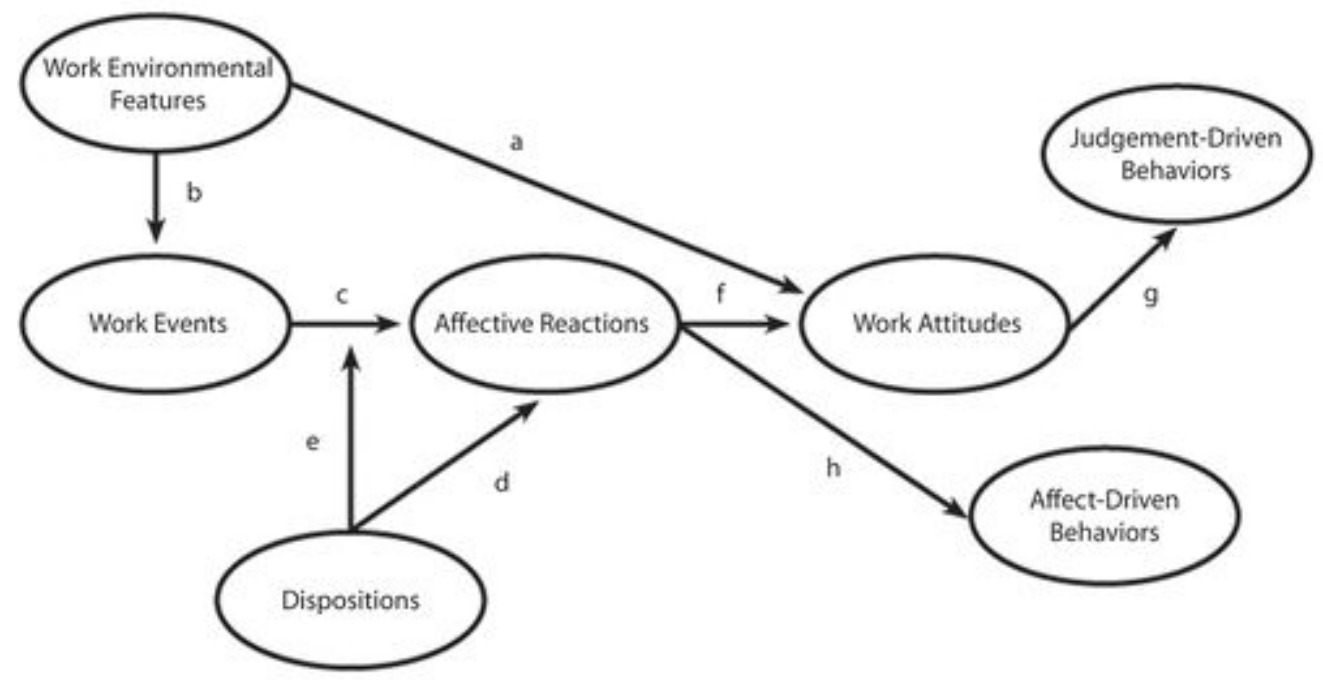

Figure 1. Graphical representation of the relationships proposed through AET. Pathways denoted by letters correspond to relationships described in the text.

Exploring different methodologies and directions

In additional to being theoretically driven, future research related to PET satisfaction should encompass a variety of research methods and methodologies. The current literature is overrepresented by quantitative, self-report survey designs that draw upon a limited number of validated questionnaires. While this research provides an abundance of important information relative to teacher satisfaction, mixed methods, and qualitative designs, including those that embrace emerging methodologies such as photovoice (Wang \& Burris, 1997) and stimulated recall interviews (Lyle, 2003), are absent in the literature. The expansion of qualitative research will help to capture teachers' narratives related to feeling satisfied or dissatisfied in their work contexts, and may uncover the type of satisfying and dissatisfying experiences unique to PETs. Carson and colleagues (2016), for example, asked PETs to chart their satisfaction levels throughout a typical school day (Surra \& Hughes, 1997) to stimulate the recollection of meaningful satisfying and dissatisfying experiences that were then discussed through interviews.

Through AET, researchers can also examine how PET satisfaction develops over time in relation to specific workplace features, and how satisfying or dissatisfying experiences result in specific behavioral outcomes, including teaching effectiveness (Carson, 2009). It is, therefore, critical that longitudinal designs be adopted. This work can similarly account for regular variations in PETs' satisfaction in response to factors such as the time of year and, for teacher/coaches, sport seasons. Observational data should also be considered to triangulate with interviews and survey responses. This research would allow researchers to discuss behavioral responses that manifest in the classroom in relation to feelings of satisfaction and dissatisfaction. Ecological momentary assessment (Carson, Weiss, \& Templin, 2010) presents an additional avenue for studying teacher satisfaction by asking PETs to respond to prompts displayed on a 
mobile device (e.g., smart phone) in real time. The immediacy of such approaches removes the need for retrospective data collection, which can be important as individuals tend to process information and reinterpret it over time (Brewer, Van Raalte, Linders, \& Van Raalte, 1991).

Implications for practice

Advancing the study of PET satisfaction has numerous implications for PE practice and the training of pre-service PETs. Job satisfaction plays a role in helping educators to survive and thrive in schools (Skaalvik \& Skaalvik, 2011). It has been connected to teacher effectiveness (Rinehart \& Short, 1994; Shann, 1998) as well as factors such as burnout (Koustelios \& Tsigilis, 2005; Platsidou \& Agaliotis, 2008), which could lead to early career attrition. The expansion of PET satisfaction scholarship could lead to research-based practices for inducting new teachers and working with experienced teachers that could be forwarded to school administrators. Over time, this could facilitate smoother transitions into the field, and help to retain experienced teachers who are motivated by their work.

Based on the results of the existing literature, it appears as if reducing student behavioral issues (Mäkelä et al., 2015), increasing pay (Koustelios \& Tsigilis, 2005), and creating feelings of job security (Amarantidou, Mantis, \& Koustelios, 2009) may result in elevated teacher satisfaction. However, these variables may be difficult to manipulate as they relate to structural elements of the workplace environment. Therefore, we also recommend that administrators seek to develop relationships with and among teachers that capitalize on their need for autonomy and support (Topič \& Mujanović, 2012), promote school and departmental cultures centered on collegiality and community (Carson et al., 2016), limit unnecessary stress in the workplace (Dhurup \& Mahomed, 2011; Shivendra \& Kumar, 2016), and help teachers retain enjoyment in their work with children (Carson et al., 2016). These approaches may help to build teacher resilience by fueling them with the capacity to persist in workplace environments that present challenging environmental features (Mansfield, Beltman, Broadley, \& Weatherby-Fell, 2016). Developing resilience in this way has been linked to reduced feelings of burnout, which may help prevent early career attrition (Richards, Levesque-Bristol, Templin, \& Graber, 2016).

In addition to improving the lived conditions of in-service PETs, we believe that lessons learned through research on PET satisfaction should be put to practice in the design and development of pre-service teacher education programs. Given that teacher education should serve to begin induction into school cultures (Richards, Templin, \& Gaudreault, 2013), teacher satisfaction research could be used to help beginning teachers understand the realities of school life and the challenges they will face. Many teacher education programs prepare pre-service PETs with the knowledge and skills required to teach, but fewer take a targeted approach to helping them understand the socio-political realities of life in school (Schempp, Sparkes, \& Templin, 1993). By introducing aspiring PETs to factors that have been found to be satisfying and dissatisfying to in-service teachers, and making them aware of the ways in which teacher satisfaction can result in behavioral responses through the lens of AET, teacher education 
programs can help equip pre-service PETs with the dispositions and resilience necessary to transition into school settings and avoid initial reality shock (Richards et al., 2013)

\section{References}

*References marked with an asterisk indicate studies included in the scoping review.

*Amarantidou, S., Mantis, K., \& Koustelios, A. (2009). Relation between job security and job satisfaction among PE teachers in Greece.International Journal of Physical Education,46(1), 20-23.

Anderson, S., Allen, P., Peckman, S., \& Goodwin, N. (2008). Asking the right questions: Scoping studies in the commissioning of research on the organization and describe of health services. Health Research Policy and Systems,6(7), 1-12. doi:10.1186/1478-4505-6-7

Arksey, H., \& O’Malley, L. (2005). Scoping studies: Toward a methodological framework. International Journal of Social Research Methodology,8,19-32. doi:10.1080/ 1364557032000119616

Avery, J. B., Wernsing, T. S., \& Luthans, F. (2008). Can positive employees help positive organiza- tional change? Impact of psychological capital and emptions on relevant attitudes and behaviors. Journal of Applied Behavioral Science,44,48-70. doi:10.1177/0021886307311470

Badri, M. A., Mohaidat, J., Ferrandino, V., \& El Mourad, T. (2013). The social cognitive model of job satisfaction among teachers: Testing and validation..International Journal of Educational Research,57,12-24. doi:10.1016/j.ijer.2012.10.007

Bogler, R. (2002). Two profiles of schoolteachers: A discriminant analysis of job satisfaction. Teaching and Teacher Education,18, 665-673. doi:10.1016/S0742-051X(02)00026-4

Booth, A., Papaioannou, D., \& Sutton, A. (2012).Systematic approaches to a successful literature reviews. London, England: Sage.

Borg, M. G., Riding, R. J., \& Falzon, J. M. (1991). Stress in teaching: A study of occupational stress and its determinants, jobs satisfaction and career commitment among primary school teachers. Educational Psychology,11,59-75. doi:10.1080/0144341910110104

Brewer, B. W., Van Raalte, J. L., Linders, D. E., \& Van Raalte, N. S. (1991). Peak performance and the perils of retrospective introspection.Journal of Sport \& Exercise Psychology,13, 227-238. doi:10.1123/jsep.13.3.227

Brief, A. P., \& Weiss, H. M. (2002). Organizational behavior: Affect in the workplace.Annual Review of Psychology,53, 279-307. doi:10.1146/annurev.psych.53.100901.135156

Briner, R. B. (1999). The neglect and importance of emotion at work.European Journal of Work and Organizational Psychology,8, 323-346. doi:10.1080/135943299398212

Buyukgoze-Kavas, A., Duff y, R. D., Güneri, O. Y., \& Autin, K. L. (2014). Job satisfaction among Turkish teachers: Exploring differences by school level.Journal of Career Assessment,22, 261-273. doi:10.1177/1069072713493980 
Carlson, D., Kacmar, K. M., Zivnuska, S., \& Ferguson, M. (2011). Work-family enrichment and job performance: A constructive replication of affective events theory.Journal of Occupational Health Psychology,16, 297-312. doi:10.1037/a0022880

Carson, R. L. (2009). "I have very little left to give": Understanding the emotional experiences of teachers and teacher burnout. In L. D. Housner, M. W. Metzler, P. G. Schempp, \& T. J. Templin (Eds.),Historic tranditions and future directions in research on teaching and teacher education in physical education(pp. 237-245). Morgantown, WV: Fitness Information Technology.

Carson, R. L., \& Raguse, A. L. (2014). Systematic review of service-learning in youth physical activity settings.Quest,66,57-95. doi:10.1080/00336297.2013.814578

*Carson, R. L., Richards, K. A. R., Hemphill, M. A., \& Templin, T. J. (2016). Exploring the job satisfaction of late career secondary physical education teachers.Journal of Teaching in Physical Education,35,284-289. doi:10.1123/jtpe.2015-0131

Carson, R. L., Weiss, H. M., \& Templin, T. J. (2010). Ecological momentary assessment: A research method for studying the daily lives of teachers.International Journal of Research \& Method in Education,33, 165-182. doi:10.1080/1743727X.2010.484548

Cochran-Smith, M., \& Zeichner, K. (2005).Studying teacher education: The report of the AERA panel on research and teacher education. Washington, DC: AERA.

Crossman, A., \& Harris, P. (2006). Job satisfaction of secondary school teachers.Educational Management Admininstration \& Leadership,34,29-46. doi:10.1177/1741143206059538

Curtner-Smith, M. (2001). The occupational socialization of a first-year physical education teacher with a teaching orientation.Sport, Education and Society,6,81-105. doi:10.1080/713696040

De Nobile, J. J., \& McCormick, J. (2008). Organizational communication and job satisfaction in Australian Catholic primary schools.Educational Management Admininstration \& Leadership, 36, 101-122. doi:10.1177/1741143207084063

*Dhurup, M., \& Mahomed, F. E. (2011). Role ambiguity, role conflict and work overload and their influence on job satisfaction of sports facilitators in public schools in the Vaal Triangle, South Africa.African Journal for Physical, Health Education, Recreation and Dance, 17, 172-188.

Dormann, C., \& Kaiser, D. M. (2002). Job conditions and customer satisfaction. European Journal of Work \& Organizational Psychology,11, 257-283. doi:10.1080/13594320244000166

Duffy, R. D., \& Lent, R. W. (2009). Test of a social cognitive model of work satisfaction in teachers. Journal of Vocational Behavior,75, 212-223. doi:10.1016/j.jvb.2009.06.001

Ellis, N. H., \& Bernhardt, R. G. (1992). Prescription for teacher satisfaction: Recognition and responsibility.Clearing House,65, 179-182. doi:10.1080/00098655.1992.10114196

Fairchild, S., Tobias, R., Corcoran, S., Djukic, M., Kovner, C., \& Noguera, P. (2012). White and black teachers'job satisfaction: Does relational demography matter?Urban Education,47,170-197. doi:10.1177/0042085911429582 
Goldring, R., Taie, S., \& Riddles, M. (2014).Teacher attrition and mobility: Results from the 2012-2013 teacher follow-up survey(NCES 2014-077). Washington, DC: U.S. Department of Education, National Center for Education Statistics. Retrieved fromhttp://nces.ed.gov/pubsearch

Goleman, D. (1988).Working with emotional intelligenceNew York, NY: Bantam Books.

*Green-Reese, S., Johnson, D. J., \& Campbell, W. A. (1991). Teacher job satisfaction and teacher job stress: School size, age and teaching experience.Education, 112, 247-252.

Griva, K., \& Joekes, K. (2003). UK teachers under stress: Can we predict wellness on the basis of characteristics of the teaching job? Psychology and Health,18, 457-471. doi:10.1080/0887044031000147193

Hersey, R. B. (1932). Rate of production and emotional state.Personnel Journal,10, 355-364.

Herzberg, F., Mausner, B., \& Snyderman, B. (1957).Job attitudes: Review of research and opinion. Pittsburg, PA: Psychological Service of Pittsburg.

Ingersoll, R. M. (2003). The teacher shortage: Myth or reality? Educational Horizons,81(3), $146-152$.

*Ješinová, L., Spurná, M., Kudláček, M., \& Sklenaříková, J. (2014). Job dissatisfaction among certified adapted physical education specialists in the USA.Acta Gymnica,44, 175- 180. doi:10.5507/ag.2014.018

Judge, T. A., Thoresen, C. J., Bono, J. E., \& Patton, G. K. (2001). The job satisfaction-job performance relationship: A qualitative and quantitative review.Psychological Bulletin,127, 376-407. doi:10.1037/0033-2909.127.3.376

Kiliç, I., \& Yazici, T. (2012). Study of job satisfaction and professional exhaustion of music teachers in fine arts and sport high schools in terms of some variables.E-Journal of New World Sciences Academy,7, 182-198.

Klassen, R. M., \& Anderson, C. J. (2009). How times change: Secondary teachers' job satisfaction and dissatisfaction in 1962 and 2007.British Educational Research Journal,35, 745-759. doi:10.1080/01411920802688721

Klassen, R. M., \& Chiu, M. M. (2010). Effects on teachers' self-efficacy and job satisfaction: Teacher gender, years of experience, and job stress.Journal of Educational Psychology,102, 741-756. doi:10.1037/a0019237

Koenig, R. (2014, October 10). Education-degree programs, once popular, take a nosedive. Chronicle of Higher Education. Retrieved fromhttp://chronicle.com/article/Education-Degree- Programs/149277/

*Kougioumtzis, K., Patriksson, G., \& Stråhlman, O. (2011). Physical education teachers'professio- nalization: A review of occupational power and professional control.European Physical Education Review, 17, 111-129. doi:10.1177/1356336X11402266

Koustelios, A. (2005). Physical education teachers in Greece: Are they satisfied? International Journal of Physical Education,42(2), 85-90. 
Koustelios, A., Theodorakis, N., \& Goulimaris, D. (2004). Role ambiguity, role conflict, and job satisfaction among physical education teachers in Greece.International Journal of Educational Management, 18,87-92.

Koustelios, A., \& Tsigilis, N. (2005). The relationship between burnout and job satisfaction among physical education teachers: A multivariate approach.European Physical Education Review,11, 189-203. doi:10.1177/1356336X05052896

*Kumar, S., \& Bhatia, R. K. (2009). Teachers and their attitude toward teaching.Asia-Paci fic Journal of Research in Business Management,2(9), 32-43.

Kyriacou, C., \& Sutcliffe, J. (1978). Teacher stress: Prevalence, sources, and symptoms.British Journal of Educational Psychology,48, 159-167. doi:10.1111/bjep.1978.48.issue-2

Lent, R. W., Nota, L., Soresi, S., Ginevra, M. C., Duffy, R. D., \& Brown, S. D. (2011). Predicting the job and life satisfaction of Italian teachers: Test of a social cognitive model.Journal of Vocational Behavior,79,91-97. doi:10.1016/j.jvb.2010.12.006

Lester, P. E. (1987). Development and factor analysis of the teacher job satisfaction questionnaire (TJSQ). Educational and Psychological Measurement,47, 223-233. doi:10.1177/0013164487471031

Levac, D., Colquhoun, H., \& O'Brien, K. (2010). Scoping studies: Advancing the methodology. Implementation Science,5, 69. doi:10.1186/1748-5908-5-69

Locke, E. A. (1969). What is job satisfaction?Organizational Behavior and Human Performance, 4, 309-336. doi:10.1016/0030-5073(69)90013-0

Locke, E. A. (1976). The nature and causes of job satisfaction.Handbook of Industrial and Organizational Psychology,1, 1297-1343.

Lux, K., \& McCullick, B. A. (2011). How one exceptional teacher navigated her working environ- ment as the teacher of a marginal subject.Journal of Teaching in Physical Education,30, 358-374. doi:10.1123/jtpe.30.4.358

Lyle, J. (2003). Stimulated recall: A report on its use in naturalistic research.British Educational Research Journal,29, 861-878. doi:10.1080/0141192032000137349

Ma, X., \& MacMillan, R. B. (1999). Influences of workplace conditions on teachers' job satisfaction. Journal of Educational Research,93,39-47. doi:10.1080/00220679909597627

Mäkelä, K., Hirvensalo, M., Laakso, L., \& Whipp, P. R. (2014). Physical education teachers in motion: An account of attrition and area transfer.Physical Education and Sport Pedagogy,19 , 418-435. doi:10.1080/17408989.2013.780590

*Mäkelä, K., Hirvensalo, M., \& Whipp, P. R. (2015). Determinants of PE teachers' career intentions. Journal of Teaching in Physical Education,34, 680-699. doi:10.1123/jtpe.2014-0081

*Mäkelä, K., \& Whipp, P. R. (2015). Career intentions of Australian physical education teachers. European Physical Education Review,21, 504-520. doi:10.1177/1356336X15584088 
Mansfield, C., Beltman, S., Broadley, T., \& Weatherby-Fell, N. (2016). Building resilience in teacher education: An evidenced informed framework.Teaching and Teacher Education,54,77-87. doi:10.1016/j.tate.2015.11.016

Markow, D., \& Pieters, A. (2012).The MetLife survey of the American teacher: Teachers, parents and the economy. New York, NY: MetLife. McBride, D. M. (2013).The process of research in psychology(2nd ed.). London, England: Sage.

McDonnell, L. M. (2012). Educational accountability and policy feedback.Educational Policy,27, 170-189. doi:10.1177/0895904812465119

McEvoy, E., MacPhail, A., \& Heikinaro-Johansson, P. (2015). Physical education teacher educators: A 25-year scoping review of literature.Teaching and Teacher Education,51, 162-181. doi:10.1016/j.tate.2015.07.005

Menon, M. E., \& Athanasoula-Reppa, A. (2011). Job satisfaction among secondary school teachers: The role of gender and experience.School Leadership \& Management,31, 435-450. doi:10.1080/ 13632434.2011.614942

Metzler, C. A. (2016). Should I stay or should I go? Understanding teacher motivation, job satisfaction, and perceptions of retention among Arizona teachers.International Research in Higher Education, 1(2), 34-45.

Montgomery, C., \& Rupp, A. A. (2005). A meta-analysis for exploring the diverse causes and effects of stress in teachers.Canadian Journal of Education,28, 458-486. doi: $10.2307 / 4126479$

*Morolia, A., \& Tiwari, D. (2012). The relationship of job stress to job satisfaction among the physical education teachers of Rajasthan.International Journal of Sports Sciences \& Fitness,2(1), 174-183.

*Mousavi, S. H., Yarmohammadi, S., Nosrat, A. B., \& Tarasi, Z. (2012). The relationship between emotional intelligence and job satisfaction of physical education teachers. Annals of Biological Research,3, 780-788.

Patton, M. Q. (2015).Qualitative research and evaluation methods(4th ed.). Thousand Oaks, CA: Sage.

Payne, R. L., \& Cooper, C. L. (2001).Emotions at work: Theory, research and applications in management . Chichester, England: John Wiley.

*Pepe, O., Turan, M. B., \& Bahadir, Z. (2015). Investigating the level of professional attitude of physical education and sports teachers in terms of some variables.Ovidius University Annals, Series Physical Education and Sport/Science, Movement and Health,15, 164-171.

Perda, D. (2013).Transitions into and out of teaching: A longitudinal analysis of early career teacher turnover(Unpublished doctoral dissertation). University of Pennsylvania, Philadelphia, PA.

Perie, M., \& Baker, D. P. (1997).Job satisfaction among America's teachers: Effects of workplace conditions, background characteristics, and teacher compensation. Washington, DC: U.S. Department of Education. 
Perrachione, B. A., Petersen, G. J., \& Rosser, V. J. (2008). Why do they stay? Elementary teachers' perceptions of job satisfaction and retention. The Professional Educator,32(2), $1-17$.

Pinder, C. C. (1998). Work motivation in organizational behavior. Upper Saddle River, NJ: Prentice Hall.

Platsidou, M., \& Agaliotis, I. (2008). Burnout, job satisfaction and instructional assignment-related sources of stress in Greek special education teachers.International Journal of Disability, Development and Education,55(1), 61-76. doi:10.1080/10349120701654613

*Reese, S., \& Johnson, D. J. (1988). School size and teacher job satisfaction of urban secondary school physical education teachers.Education, 108, 382-384.

Rhodes, C., Nevill, A., \& Allan, J. (2004). Valuing and supporting teachers: A survey of teacher satisfaction, dissatisfaction, morale and retention in an English local education authority. Research in Education,71,67-80. doi:10.7227/RIE.71.7

Richards, K. A. R., Gaudreault, K. L., \& Woods, A. M. (2016). Understanding physical educators' perceived mattering: Validation of the perceived mattering questionnaire_-Physical education. European Physical Education Review. doi:10.1177/1356336X16637320

Richards, K. A. R., Levesque-Bristol, C., Templin, T. J., \& Graber, K. (2016). The impact of resilience on role stressors and burnout in elementary and secondary teachers.Social Psychology of Education,19, 511-536. doi:10.1007/s11218-016-9346-X

Richards, K. A. R., \& Templin, T. J. (2012). Toward a multidimensional perspective on teachercoach role conflict.Quest,64, 164-176. doi:10.1080/00336297.2012.693751

Richards, K. A. R., Templin, T. J., \& Gaudreault, K. L. (2013). Understanding the realities of school life: Recommendations for the preparation of physical education teachers.Quest,65, 442-457. doi:10.1080/00336297.2013.804850

Richardson, V., \& Placier, P. (2001). Teacher change. In V. Richardson (Ed.),Handbook of research on teaching(4th ed., pp. 905-947). Washington, DC: American Educational Research Association.

Rinehart, J. S., \& Short, P. M. (1994). Job satisfaction and empowerment among teacher leaders, reading recovery teachers, and regular classroom teachers.Education, 114, 570-580.

Rupp, D. E., \& Spencer, S. (2006). When customers lash out: The effects of customer interactional injustice on emotional labor and the mediating of discrete emotions.Journal of Applied Psychology,91, 971-978. doi:10.1037/0021-9010.91.4.971

*Rutkowska, K., \& Zalech, M. (2015). Job satisfaction of a physical education teacher as seen by school community.Physical Culture and Sport. Studies and Research,68,34-42. doi:10.1515/ pcssr-2015-0026

Ryan, K. (Ed.) (1970).Don't smile until Christmas: Accounts of the first year of teaching. Chicago, IL: University of Chicago Press. 
Schempp, P. G., Sparkes, A., \& Templin, T. J. (1993). The micropolitics of teacher induction. American Educational Research Journal,30, 447-472. doi:10.3102/00028312030003447

*Şentuna, M. (2015). Investigation of job satisfaction, organizational commitment and self-esteem of physical education teachers according to gender.International Online Journal of Educational Sciences, 7(2), 93-101.

Shann, M. H. (1998). Professional commitment and satisfaction among teachers in urban middle schools.Journal of Educational Research,92(2), 67- 73. doi:10.1080/00220679809597578

*Shivendra, D., \& Kumar, M. M. (2016). A study of job satisfaction and job stress among physical education teachers working in government, semi-government and private schools.International Journal of Sports Sciences \& Fitness, 6,89-100.

Skaalvik, E. M., \& Skaalvik, S. (2011). Teacher job satisfaction and motivation to leave the teaching profession: Relations with school context, feeling of belonging, and emotional exhaustion. Teaching and Teacher Education,27, 1029-1038. doi:10.1016/j.tate.2011.04.001

Surra, C. A., \& Hughes, D. K. (1997). Commitment processes in accounts of the development of premarital relationships.Journal of Marriage and the Family,59,5-21. doi:10.2307/353658

*Topič, M. D., \& Mujanović,Š. (2012). Slovenian physical education teachers' satisfaction at work: Analysis of some important factors which strongly influence job satisfaction.Ido Movement for Culture: Journal of Martial Arts Anthropology: Theory of Culture, Psychophysical Culture, Cultural Tourism, Anthropology of Martial Arts, Combat Sport,12,1-6.

Valli, L., Croninger, R. G., \& Walters, K. (2007). Who (else) is the teacher? Cautionary notes on teacher accountability systems.American Journal of Education,113, 635-662. doi:10.1086/518492

Van Maele, D., \& Van Houtte, M. (2012). The role of teacher and faculty trust in forming teachers' job satisfaction: Do years of experience make a difference?Teaching and Teacher Education,28, 879-889. doi:10.1016/j.tate.2012.04.001

Wang, C., \& Burris, M. A. (1997). Photovoice: Concept, methodology, and use for participatory needs assessment.Health Education \& Behavior,24, 369-387. doi:10.1177/109019819702400309

Wegge, J., Van Dick, R., Fisher, G. K., West, M. A., \& Dawson, J. F. (2006). A test of basic assumptions of affective events theory in call centre work.British Journal of Management,17, 237-254. doi:10.1111/j.1467-8551.2006.00489.x

Weiss,D.J.,Dawis,R.V.,England,G.W.,\&Lofquist,L.H.(1967).Manual for the Minnesota satisfaction questionnaire(Vol. XXII). Minneapolis, MN: University of Minnesota, Industrial Relations Center.

Weiss, H. M. (2002). Deconstructing job satisfaction: Separating evaluations, beliefs and affective experiences.Human Resource Management Review ,12, 173-194. doi:10.1016/S1053-4822(02)00045-1 
Weiss, H. M., \& Cropanzano, R. (1996). Affective events theory: A theoretical discussion of the structure, causes and consequences of affective experiences at work.Research in Organizational Behavior, 18,1-74.

*Yildirim, I. (2015). A study on physical education teachers: The correlation between self-efficacy and job satisfaction.Education, 136(2), 92-104.

Zhao, H., Wayne, S. J., Glibkowski, B. C., \& Bravo, J. (2007). The impact of psychological contract breach on work-related outcomes: A meta-analysis.Personnel Psychology,60, 647-680. doi:10.1111/peps.2007.60.issue-3 